\title{
Reversible Vertebral Artery Stenosis following Corticotherapy in Giant Cell Arteritis
}

\author{
Rechdi Ahdab Florent Thabuy Eude Menager de Froberville Pierre Brugieres \\ Hassan Hosseini \\ Henri Mondor Hospital, Creteil, France
}

A 76-year-old patient presented with acute-onset vertigo and ataxia preceded by temporal headaches and jaw claudication. MRI disclosed cerebellar strokes and bilateral vertebral artery stenosis. Temporal artery biopsy revealed giant cell arteritis. Arterial lesions reversed following 10 days of oral prednisone $(60 \mathrm{mg})$ and anticoagulation.

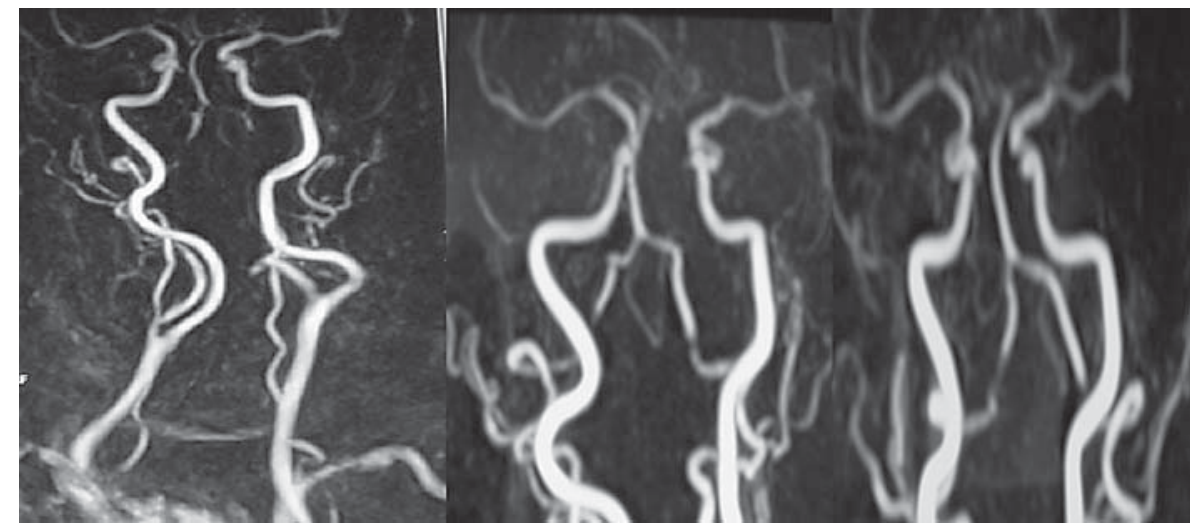

Fig. 1. Initial cervical MRA revealing severe stenosis of both vertebral arteries (left). Following steroids, significant repermeabilization of the vertebral arteries (middle, right). The level of stenosis is identical in both arteries and corresponds to the junction between the intracranial and extracranial portions.

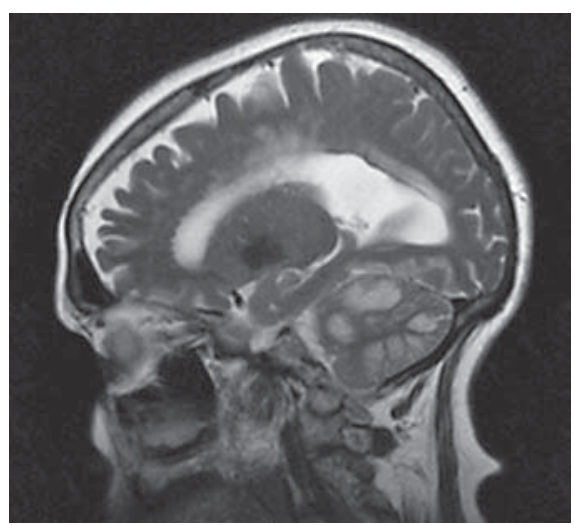

Fig. 2. Sagittal $\mathrm{T}_{2}$-weighted MRI revealing widespread cerebellar stroke.

\section{KARGER}

Fax +41613061234 E-Mail karger@karger.ch www.karger.com
(C) 2008 S. Karger AG, Basel

0014-3022/08/0596-0331\$24.50/0

Accessible online at: www.karger.com/ene
Rechdi Ahdab

23 Rue Friant

FR-75014 Paris (France)

Tel. +33 627880 359, Fax +33 149812326

E-Mail chadahdab@hotmail.com 